\title{
Pharyngeal Cancer TNM Finding v8
}

National Cancer Institute

\section{Source}

National Cancer Institute. Pharyngeal Cancer TNM Finding v8. NCI Thesaurus. Code C132791.

A finding about one or more characteristics of pharyngeal cancer, following the rules of the TNM AJCC v8 classification system. (from AJCC 8th Ed.) 